\title{
RESEPSI ATAS PERUPA JERMAN PADA HARIAN KOMPAS DAN MAJALAH TEMPO EDISI 2000 - 2007
}

\author{
Oleh: \\ Dian Swandayani, Nurhadi, Iman Santoso \\ Staf Pengajar FBS UNY
}

\begin{abstract}
Indonesian culture gets a big influence of foreign culture. The acculturation of the culture has been going on until today. Media becomes a vehicle for spreading the foreign culture in the modern era. In the media certain values are contested to gain major influence. One of the cultural aspects getting the foreign cultural influence is fine arts. In this field, Germany is one of the developed countries that develop fine arts and promote (penetrate) culture, particularly fine arts, to other countries in the world, including Indonesia. Regarding the fact, this article tries to explain the Indonesian society's reception of German fine artists and their works as reflected in articles published in Kompas daily and Tempo magazine in 2000-2007 edition. Reception theory and content analysis were used in this study that tried to find the pattern and form of acculturation of German culture in Indonesia today.
\end{abstract}

Keywords: Reception theory, media, german fine artists, acculturation

\section{PENDAHULUAN}

Seperti yang sudah diketahui oleh banyak kalangan, bahwa Indonesia memiliki letak geografis yang sangat strategis, karena terletak di antara dua benua (Asia dan Australia) serta diapit oleh dua samudra (Samudra Hindia dan Samudra Pasifik). Posisi strategis yang dimiliki oleh Indonesia ini menjadikan Indonesia sejak dahulu kala menjadi daerah perlintasan atau persilangan berbagai kebudayaan. Bangsa Indonesia boleh dikatakan merupakan bangsa yang dalam perjalanan sejarahnya sebagai sebuah bangsa yang menerima banyak sekali pengaruh asing dalam membentuk identitas dirinya.

Akulturasi dengan budaya Eropa, seperti Portugis, Belanda, termasuk Cina, India, Arab, dan pengaruh budaya-budaya lainlah 
yang menandai masuknya pengaruh modernisme di Indonesia. Hal ini juga ditegaskan oleh Lombard (2000:11 - 39) bahwa Indonesia selama ini telah mendapat pengaruh dari budaya-budaya besar dunia seperti India, Cina, Islam dan Barat. Pengaruh budaya eropa (sebagai wakil dunia barat) terhadap perkembangan budaya Indonesia tersebut secara tidak langsung dimulai ketika bangsa Portugis dan Spanyol memulai misi dagangnya hingga ke wilayah kepulauan Indonesia pada awal abad 16 (Kubitschek dan Wessel, 1981: 43). Hingga kini proses akulturasi budaya masih terus berlangsung. Ada berbagai aspek budaya asing yang diterima dan diserap sebagai salah satu elemen pembentuk identitas bangsa yang terus mengalami perubahan, seperti bidang filsafat, sastra, seni, budaya, ilmu pengetahuan dan teknologi

Bahkan di akhir abad 20 hingga awal abad 21 persinggungan berbagai aspek kebudayaan di Indonesia semakin intensif terjadi. Dunia saat ini ditandai dengan fenomena yang oleh Alvin Toffler (1991:19) disebut dengan the third wave, yakni sebuah perubahan gaya hidup yang menggoncang segi-segi kehidupan, yakni goncangan gelombang kebudayaan manusia yang ditandai dengan perubahan tingkat informasi. Revolusi kebudayaan yang ketiga - menurut Toffler - ditandai dengan perubahan yang cepat yang mendasarkan pada perkembangan informasi sebagaimana yang kini dikenal dengan dunia komputerisasi dan internet. Kemajuan penemuan di bidang teknologi informasi mengakibatkan dunia seolah menjadi tanpa batas dan berubah menjadi sebuah kampung besar, sehingga kontak ataupun persinggungan antar budaya menjadi lebih mudah dan berlangsung dalam hitungan waktu yang sedemikian cepat. Sebuah keluarga di awal abad ke-21 ditandai dengan hubungan antar-anggotanya yang tersebar di berbagai wilayah dunia. Untuk berkomunikasi, mereka terhubung oleh seperangkat alat elektronik. Anak-anak mereka tidak lagi berbahasa Indonesia dan berbudaya Jawa. Mereka adalah anakanak dunia yang mengenal berbagai pengaruh budaya dunia tempat mereka tumbuh dan bersinggungan dengan budaya lain yang 
mereka singgahi. Bahasa mereka tidak lagi Jawa atau Indonesia, tetapi mereka mahir memanfaatkan bahasa internasional untuk berkomunikasi. Mereka bahkan menikah dengan orang-orang dari benua yang berbeda. Fenomena semacam itulah yang menandai kehidupan budaya orang-orang di milenium ketiga, orang-orang multikulturalisme. Dalam arus pertukaran kebudayaan yang berlangsung secara cepat ini, masing-masing individu akan bersinggungan dengan kebudayaan lain. Akan terjadi akulturasi, penyebaran pengaruh, ataupun adopsi dan adaptasi suatu budaya oleh budaya lain.

Salah satu bangsa Eropa yang turut memberikan pengaruh di bidang kebudayaan bagi perkembangan kebudayaan di Indonesia adalah Jerman, walau harus diakui pengaruh tersebut tidaklah sebesar bangsa Belanda yang telah menduduki Indonesia sebagai negara jajahannya selama berabad-abad. Meski jejak pengaruh bangsa Jerman secara langsung di Indonesia relatif sedikit, namun tidaklah bisa dipandang sebelah mata. Siebert (2002) dalam bukunya berjudul "Berjejak di Indonesia" menunjukan bahwa dalam rentang waktu yang cukup lama ada 10 tokoh yang cukup berpengaruh dalam perjalanan sejarah bangsa Indonesia. Para tokoh tersebut berkecimpung dalam berbagai bidang, mulai dari Gustav Wilhelm Baron van Imhoff yang pernah menjadi Gubernur Hindia Belanda, Franz Wilhelm Junghun yang merupakan seorang dokter dan peneliti alam, hingga Franz Magnis Suseno seorang rohaniwan yang hingga saat ini masih dipandang sebagai salah satu tokoh terkemuka bidang filsafat di Indonesia. Jejak bangsa Jerman juga tampak dalam bidang kesenian dan sastra. Tokohnya antara lain Max Dauthendey, seorang pujangga dan Walter Spiess seorang pelukis sekaligus musisi yang cukup lama tinggal di Bali dan turut mempengaruhi perkembangan seni lukis modern di Bali.

Saat ini proses akulturasi tersebut terus berlangsung, termasuk di bidang seni rupa sebagai salah satu bagian dari kebudayaan. Terkait dengan hal itu, dirasa sangat relevan untuk mengkaji seberapa jauh para perupa Jerman diresepsi oleh masyarakat 
(pembaca) Indonesia. Salah satu cara untuk mengetahui resepsi pembaca tersebut yaitu dengan menelaah seberapa besar karyakarya perupa Jerman tersebut mendapat tanggapan dalam media massa. Penelaahan terhadap tanggapan dalam media massa cukup penting, karena melalui media massa penyebaran pengaruh budaya lain dapat berlangsung dengan cepat, mengingat luasnya jangkauan sebaran media massa. Media massa yang dipilih adalah harian Kompas, sebagai salah satu harian terkemuka di Indonesia yang memiliki oplah terbesar dan majalah mingguan Tempo sebagai wakil majalah yang cukup terpandang. Sedangkan edisi yang dipilih adalah edisi yang terbit antara tahun 2000 hingga 2007. Periode ini cukup penting, karena dianggap sebagai tonggak millennium.

Pisau analisis yang bisa dijadikan landasan untuk mengupas tanggapan dalam media massa terhadap perupa Jerman adalah teori resepsi sastra. Resepsi sastra adalah pengolahan teks, cara-cara pemberian makna terhadap karya sastra sehingga dapat memberi tanggapan terhadapnya. Tanggapan yang dimaksud tidak hanya dilakukan antara karya dengan seorang pembaca, tetapi juga pembaca sebagai proses sejarah, pembaca dalam periode tertentu. Estetika resepsi secara ringkas dapat disebut sebagai suatu ajaran yang menyelidiki teks sastra berdasarkan reaksi pembaca yang nyata dan yang mungkin terhadap karya sastra. Dalam estetika resepsi, yang menjadi perhatian utama yaitu pembaca karya sastra dan masyarakat pembaca. Pembaca, menurut Jausz (1974:12), mempunyai peranan aktif, bahkan merupakan kekuatan pembentuk sejarah.

Terkait dengan teori tersebut, karya seni rupa seorang seniman bisa diibaratkan atau dianalogikan sebagai sebuah karya sastra, sehngga bisa dianalisis menggunakan teori resepsi sastra. Karya seni rupa, tidak jauh beda dengan karya sastra merupakan hasil karya imajinatif seorang perupa yang seringkali merefleksikan pandangan ataupun latar belakang kehidupan sosial yang dialami oleh pembuatnya. 
Berdasarkan latar belakang tersebut, maka dalam artikel ini akan dibahas hal-hal yang terkait dengan: (1) artikel apa sajakah yang memuat karya perupa Jerman dalam harian Kompas dan Majalah Tempo edisi 2000 - 2007, (2) mendeskripsikan tanggapan Harian Kompas dan Majalah Tempo atas perupa Jerman tersebut dan (3) mendeskripsikan bentuk komunitas interpretasi yang dilakukan oleh Harian Kompas dan Majalah Tempo terhadap karya-karya perupa Jerman tersebut sebagai salah satu bentuk konstruksi atau formasi sosial.

\section{Artikel di Harian Kompas dan Majalah Tempo yang memuat Perupa Jerman}

Di Indonesia, harian Kompas merupakan salah satu harian terkemuka yang memiliki tiras cukup besar dan menjangkau hampir seluruh pelosok tanah air. Harian Kompas pertama kali terbit pada tanggal 28 Juni 1965 dengan menggunakan moto "Amanat Hati Nurani Rakyat" dan tetap bertahan hingga saat ini. Harian Kompas tercatat memiki jumlah oplah yang cukup besar. Pada tahun 2004 tiras hariannya mencapai 530.000 eksemplar dan memiliki jumlah pembaca sebanyak 2,25 juta (http://id.wikipedia.org/wiki/KOMPAS). Dengan usianya yang mencapai 44 tahun dan jumlah pembacanya yang cukup besar, membuat harian Kompas merupakan sebuah harian yang cukup berpengaruh dalam menyebarkan informasi, termasuk dalam menyebarkan pengaruh budaya eropa (Jerman).

Di sisi lain majalah Tempo yang pertama kali didirikan pada tahun 1971 juga merupakan majalah yang turut mewarnai perjalanan sejarah bangsa Indonesia, terutama karena independensinya dan kekritisannya pada pemerintah. Majalah Tempo pernah dilarang terbit oleh pemerintah pada tahun 1982 dan 21 Juni 1994 dan kembali beredar pada 6 Oktober 1998. (http://id.wikipedia.org/wiki/Majalah_Tempo). Meski harian Kompas, maupun majalah Tempo bukanlah media massa yang mengkhususkan diri pada bidang seni dan budaya, kedua media 
massa tersebut memiliki rubrik mengenai seni dan budaya yang terbit secara rutin. Atas dasar pemikiran itulah, kedua media massa tersebut dipilih sebagai objek kajian mengenai tanggapan kedua media massa tersebut terhadap perupa Jerman dan karyanya.

Selama kurun waktu antara tahun 2000 hingga 2007, majalah Tempo telah menerbitkan artikel berupa tanggapan terhadap perupa Jerman sebanyak 7 buah artikel. Sedangkan harian Kompas menerbitkan artikel yang menanggapi perupa Jerman sebanyak 13 artikel. Dalam kurun waktu tersebut, memang jumlah artikel mengenai perupa Jerman secara kuantitatif tidaklah banyak, namun jika ditelusuri tahun penerbitan artikel, terlihat bahwa setiap tahun sejak tahun 2000 hinga 2006 selalu ada artikel mengenai perupa Jerman dan karyanya di harian Kompas dan majalah Tempo. Hanya pada tahun 2007 tidak ada artikel mengenai perupa Jerman.

Hal ini menunjukan, bahwa perupa Jerman cukup dihargai di Indonesia, terbukti dari rutinya karya mereka ditampilkan dalam bentuk pameran tunggal maupun bersama yang ditanggapi oleh media massa tersebut. Di satu sisi, tanggapan terhadap perupa Jerman juga menunjukan adanya proses akulturasi budaya dalam bidang seni rupa, karena melalui tanggapan penulis dalam bentuk artikel itulah kemudian konsep (termasuk ideologi) sebuah karya seni disebarluaskan.

Tanggapan yang berwujud artikel tersebut muncul untuk menanggapi berbagai kegiatan pameran seni rupa yang dilakukan oleh perupa Jerman ataupun untuk menanggapi eksistensi seorang perupa dalam khasanah seni rupa yang telah diakui dunia. Perupa yang memperoleh tanggapan dari harian Kompas dan majalah Tempo berjumlah 42 orang. Mereka mewakili berbagai aliran dalam seni rupa.

Berdasarkan tabel 1, terlihat bahwa terdapat beberapa nama perupa (Kelompok perupa) yang memperoleh liputan baik di harian Kompas maupun majalah Tempo, yaitu Peter Dittmar, Sigmar Polke, Günther Uecker, Max Ernst serta Monica Bonvicini dkk. Munculnya tanggapan dalam bentuk artikel seni rupa terhadap 
para perupa tersebut menandakan bahwa karya-karya mereka cukup diakui, terutama di Indonesia, sehingga kedua media massa tersebut memberikan tanggapan khusus terhadap karya mereka. Perupa yang lain yang hanya memperoleh tanggapan satu kali di harian Kompas atau di majalah Tempo antara lain Dieke Ambroster dkk, Rotraut Pape, Anna Anders dkk, Georg Baselitz, Beate Guschow, Blala Halman, Wolfgang Thesen, Kathe Kölwitz, Markus Heinsdorf. Gambaran selengkapnya mengenai artikelartikel tersebut dapat dilihat pada grafik 1 dan tabel 1 berikut ini:

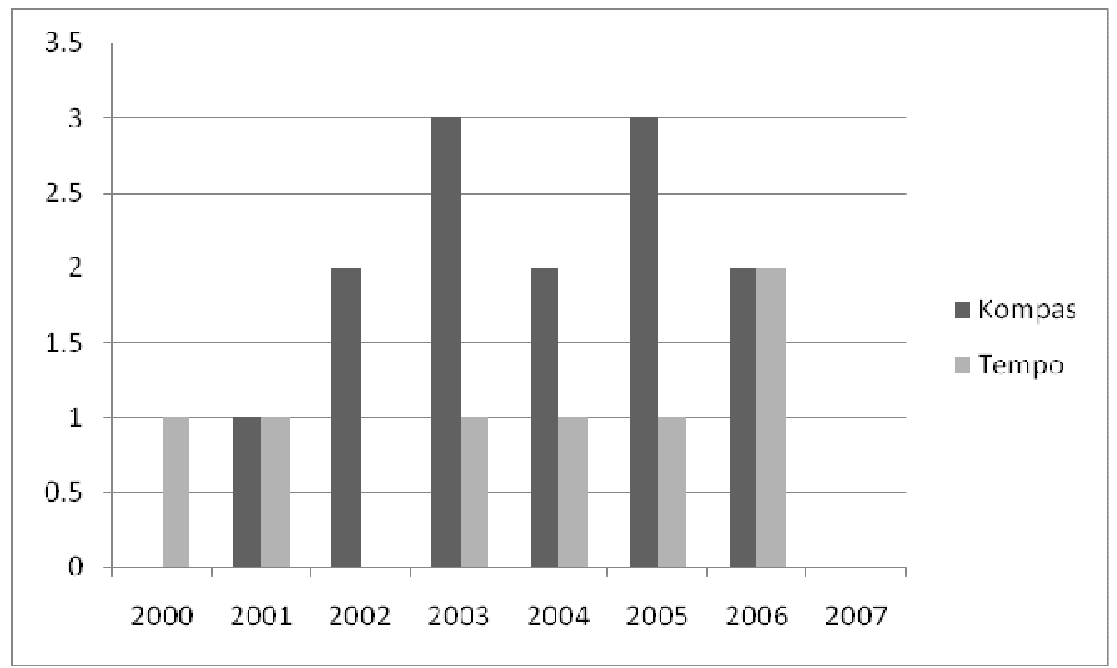

Gambar 1. Jumlah Artikel Tentang Perupa Jerman berdasarkan Tahun Penerbitan 
Tabel 1. Artikel Tentang Perupa Jerman yang dimuat di harian Kompas dan Majalah Mingguan Tempo Tahun 2000 - 2007

\begin{tabular}{|c|c|c|c|c|}
\hline \multirow{2}{*}{ No } & \multirow{2}{*}{ Nama Perupa (Seniman) } & \multicolumn{2}{|c|}{ Dimuat di } & \multirow{2}{*}{$\begin{array}{l}\text { Jumlah } \\
\text { Perupa }\end{array}$} \\
\hline & & Kompas & Tempo & \\
\hline 1 & Peter Dittmar & $\begin{array}{l}\text { Minggu, } 09 \text { Oct } \\
2005\end{array}$ & $\begin{array}{l}\text { No. } \\
\text { 32/XXXV/2-8 } \\
\text { Oktober } 2006\end{array}$ & 1 \\
\hline 2 & Sigmar Polke & $\begin{array}{l}\text { Sabtu, 05 Aug } \\
2006 \text { dan } \\
\text { Minggu, 06 } \\
\text { Aug 2006 }\end{array}$ & $\begin{array}{l}\text { No. } \\
\text { 25/XXXV/14 - } \\
20 \text { Agustus } \\
2006\end{array}$ & 1 \\
\hline 3 & Günther Uecker & $\begin{array}{l}\text { Minggu, } 07 \\
\text { Aug } 2005\end{array}$ & $\begin{array}{l}\text { Tempo, No. } \\
\text { 25/XXXIV/15 } \\
\text { - } 21 \text { Agustus } \\
2005\end{array}$ & 1 \\
\hline 4 & Max Ernst & $\begin{array}{l}\text { Rabu, 07 Jan } \\
2004\end{array}$ & $\begin{array}{l}\text { No. } \\
\text { 47/XXXII/19 - } \\
\text { 25 Januari } \\
2004\end{array}$ & 1 \\
\hline 5 & $\begin{array}{l}\text { Dieke Armbroster, Frank } \\
\text { von Grafenstein, Manuel } \\
\text { Werner, Rainer } \\
\text { Czarnetzki, Kim Dotty } \\
\text { Hachmann, Gesa Lange }\end{array}$ & - & $\begin{array}{l}\text { No. } \\
\text { 18/XXXII/29 } \\
\text { Juni - 06 Juli } \\
2003\end{array}$ & 6 \\
\hline 6 & $\begin{array}{l}\text { Wolf Vostell, Anna } \\
\text { Anders, Claus Bohmier, } \\
\text { Birgit Brenner, Klaus vom } \\
\text { Bruch, Ingo Gunther, } \\
\text { Jean-Francois Guiton, } \\
\text { Wolf Kahlen, Dieter } \\
\text { Kiessling, Franziska } \\
\text { Megert, Marcel } \\
\text { Oldenbach, Ulrike } \\
\text { Rosenbach, Reiner } \\
\text { Ruthenbeck, Jeffrey } \\
\text { Shaw, Wolfgang Staehle, } \\
\text { dan Herbert Wentscher. }\end{array}$ & $\begin{array}{l}\text { Sabtu, } 13 \text { Oct } \\
2001\end{array}$ & $\begin{array}{l}\text { NO. } \\
\text { 33/XXX/15 - } \\
21 \text { Oktober } \\
2001\end{array}$ & 16 \\
\hline
\end{tabular}




\begin{tabular}{|c|c|c|c|c|}
\hline \multirow{2}{*}{ No } & \multirow{2}{*}{ Nama Perupa (Seniman) } & \multicolumn{2}{|c|}{ Dimuat di } & \multirow{2}{*}{$\begin{array}{l}\text { Jumlah } \\
\text { Perupa }\end{array}$} \\
\hline & & Kompas & Tempo & \\
\hline 7 & Rotraut Pape & - & $\begin{array}{l}\text { Tempo, NO. } \\
\text { 13/XXIX/29 } \\
\text { Mei - 4 Juni } \\
2000\end{array}$ & 1 \\
\hline 8 & $\begin{array}{l}\text { Anna Anders, Claus } \\
\text { Bohmier, Birgit Brenner, } \\
\text { Klaus vom } \\
\text { Bruch, Ingo Gunther, } \\
\text { Jean-Francois Guiton, } \\
\text { Wolf Kahlen, Dieter } \\
\text { Kiessling, Franziska } \\
\text { Megert, Marcel } \\
\text { Oldenbach, Ulrike } \\
\text { Rosenbach, Reiner } \\
\text { Ruthenbeck, Jeffrey } \\
\text { Shaw, Wolfgang Staehle, } \\
\text { dan Herbert Wentscher. }\end{array}$ & $\begin{array}{l}\text { Minggu, 12 Jun } \\
2005\end{array}$ & - & 17 \\
\hline 9 & Georg Baselitz & $\begin{array}{l}\text { Minggu, } 02 \\
\text { May } 2004\end{array}$ & - & 1 \\
\hline 10 & $\begin{array}{l}\text { Beate Gutschow, Blala } \\
\text { Halmann. }\end{array}$ & $\begin{array}{l}\text { Minggu, } 16 \\
\text { Nov } 2003\end{array}$ & - & 2 \\
\hline 11 & Wolfgang Thesen & $\begin{array}{l}\text { Selasa, 01 Apr } \\
2003\end{array}$ & - & 1 \\
\hline 12 & Kathe Kollwitz & $\begin{array}{l}\text { Senin, 09 Dec } \\
2002\end{array}$ & - & 1 \\
\hline 13 & Markus Heinsdorf & $\begin{array}{l}\text { Minggu, } 06 \text { Oct } \\
2002\end{array}$ & - & 1 \\
\hline & Jumlah & 13 Artikel & 7 Artikel & $\begin{array}{c}50 \\
\text { Perupa } \\
\end{array}$ \\
\hline
\end{tabular}

Tanggapan Harian Kompas dan Majalah Tempo terhadap Perupa Jerman dan Karyanya

Artikel yang ditulis oleh para penulis di harian Kompas dan majalah Tempo merupakan karya dari pembaca kreatif yang menuliskan kembali tanggapan "pembacaannya" terhadap sebuah karya seni rupa yang dibuat oleh orang lain menjadi sebuah tulisan 
yang berisi kajian mengenai karya seni rupa tersebut, dalam hal ini adalah karya perupa Jerman. Dalam tulisan-tulisan tersebut akan terlihat dengan jelas bagaimana seorang pembaca kreatif menanggapi karya perupa Jerman. Karya seni rupa yang dikaji meliputi berbagai bentuk, mulai dari seni lukis, seni patung karya cetak, seni instalasi dan seni video.

Tanggapan yang diberikan penulis resensi di harian Kompas dan majalah mingguan Tempo cukup beragam dan tangggapan yang diberikan juga cukup kritis. Para penulis tersebut dapat dengan jelas memberikan deskripsi mengenai karya-karya senirupa yang dihasilkan oleh perupa Jerman, termasuk penjelasan mengenai proses kreatif para perupa tersebut dan aspek-aspek yang melatarbelakangi sebuah penciptaan karya seni rupa. Para pembaca Kompas dan Tempo akan memperoleh gambaran yang cukup baik mengenai ciri-ciri yang menonjol pada setiap karya perupa Jerman tersebut, sekaligus untuk memahami makna yang tersurat maupun tersirat pada karya-karya tersebut.

Karya-karya yang ditanggapi tersebut sebagian besar merupakan karya yang dipamerkan di Indonesia, kecuali karya Beate Gutschow, Blala Halmann yang dipamerkan pada Art Cologne tahun 2003 di Koln, Jerman. Diantara artikel yang dimuat, ada satu esei dari Enin Supriyanto yang khusus memberikan kajian pada karya Kathe Kölwitz, yang digunakan sebagai panduan untuk Trienal Grafis 2003 di Bentara Budaya Jakarta. Trienal Grafis ini merupakan semacam kompetisi bagi seniman-seniman Indonesia. Pada kompetisi tersebut motiv yang selalu dimunculkan oleh Kölwitz yaitu "Kematian" menjadi motiv utama yang harus dipakai oleh para seniman untuk bisa mengikutkan karyanya dalam Trienal Grafis tersebut.

Berdasarkan data yang ada, para penulis artikel adalah para profesional di bidang masing-masing. Diantaranya berprofesi sebagai wartawan, kurator seni, pengamat seni, penulis buku, perupa, pengajar di perguruan tinggi dan kurator museum di Berlin yaitu Ludger Derenthal yang menuliskan esei tentang Max Ernst. 
Secara garis besar mereka memberikan tanggapan yang positif terhadap perupa Jerman, meskipun ada pula penulis yang memberikan kritik terhadap sebuah karya. Dengan demikian secara umum, tampaknya para perupa Jerman diresepsi sebagai tokohtokoh yang menawarkan konsep dan pemikiran baru di bidang seni rupa di Indonesia.

\section{Bentuk Konstruksi Sosial Terhadap Perupa Jerman di Indonesia}

Dari sekian banyak perupa (seniman) Jerman, yang paling banyak dibahas adalah Sigmar Polke, karena terdapat tiga buah artikel yang ditulis khusus untuk menanggapi karya Polke yang dipamerkan di Jakarta. Bersama rekannya Gerhard Richter, Polke menciptakan formulasi seni lukis yang disebut "Realisme Kapitalis" (Capitalist Realism) sebagai cemoohan terhadap aliran Realisme Sosialis yang menjadi doktrin seni resmi di negara-negara Komunis. Lukisan-lukisan karya Polke memiliki ciri khas tersendiri, karena karya-karyanya sulit (ia sendiri menolak) untuk diidentifikasi dengan cara-cara yang "pasti" dan "tertib". Dalam pemberian judul karyanya misalnya, Polke acap kali bermain dengan kata-kata yang seringkali mengaburkan makna.

Sigmar Polke yang dilahirkan di Oels, bekas Jerman Timur pada tahun 1941, memiliki kedalaman pemikiran dan sekaligus semangat pemberontakan yang tercermin dalam karya-karyanya. Saat ini Polke merupakan salah satu nama besar dalam perjalanan seni rupa modern Jerman yang telah memperoleh berbagai jenis penghargaan seni rupa. Menurut Agung Hujatnikajennong Kurator dan Pengajar di FSRD ITB - , Polke adalah "seniman jenius yang sangat sadar akan potensi-potensi tak terduga dari permainan metafor, bahkan ketika ia harus menggunakan ungkapan-ungkapan yang tak banyak dikenal oleh publik.." (Kompas, 06 Agustus 2006).

Nama besar perupa Jerman yang juga banyak disinggung di harian Kompas dan majalah Tempo adalah Max Ernst. Max Ernst 
adalah seniman Jerman yang hidup antara tahun 1891 hingga 1976 dan merupakan salah seorang pelopor gerakan dadaisme serta surrealisme. Ia banyak dipengaruhi oleh seniman Prancis yang juga merupakan pelopor utama gerakan surealis yaitu Andre Bretton, serta berteman akrab dengan Sosiolog terpandang Levis Straus dan Fisikawan Martin Heisenberg. Sebagai salah seorang pelopor, amatlah pantas jika kemudian pada tahun 2005 di kota kelahirannya Brühl, Jerman didirikan museum senirupa yang diberi nama Max Ernst Museum. Max Ernst tidak hanya melahirkan karya lukis, namun ia juga banyak menghasilkan karya berupa patung, karya grafis dan bahkan menulis buku serta puisi yang beraliran surealis. Ernst dikenal memelopori teknik Frottage, Grattage dan decalcomania.

Dalam perjalanan berkeseniannya, Max Ernst banyak dipengaruhi oleh kebudayaan lain di luar kebudayaan eropa. Baginya sangat penting untuk menggeluti karya-karya seni di luar kebudayaan eropa. Terkait dengan karya seni tersebut, Derenthal (Kompas, 07 Januari 2004) mengatakan:".. Dalam hal ini dia dapat melihat bagaimana dari sebuah konteks kultural yang lain muncul sebuah pengalaman dunia yang secara struktural punya muatan yang sama". Sebagai seniman surrealis, Ernst banyak belajar dari para seniman-empu masyarakat primitif di luar kebudayaan eropa, misal karya para seniman suku Indian, seperti yang tampak dalam karya patungnya yang terkenal yaitu Capricorn. Tidaklah mengherankan jika Ernst dikenal sebagai seorang seniman yang hidup di alam modern dengan pikiran yang selalu menerawang alam mitologi.

Selain Max Ernst dan Sigmar Polke, perupa Günther Uecker juga memilik reputasi yang diakui secara internasional dan telah memperoleh berbagai penghargaan. Pada tahun 2000 ia memperoleh Pour le mérite für Wissenschaft und Künste dan pada tahun 2006 ia meraih penghargaan Berliner Bär(BZ-Kulturpreis).

Günther Uecker dikenal dengan karyanya yang banyak menggunakan paku sebagai media estetik. Selain paku, ia juga 
banyak menggunakan media atau benda yang sehari-hari amat dikenal, bahkan bahan-bahan yang "murah". Namun, dari kesederhanaan media estetiknya itulah, karya-karya Uecker memiliki daya tarik tersendiri. Tisna Sanjaya, seorang perupa Bandung, memberikan apresiasi yang cukup tinggi pada Uecker. Menurutnya, karya-karya Uecker tidak hanya sebatas penyajian yang imajiner, tapi juga mampu memberikan inspirasi pada penikmat seni atau perupa seperti dirinya untuk melakukan perjalanan pencarian jati diri melalui praktika dengan bahan-bahan yang dapat dijumpai sehari-hari.

Penggunaan paku sebagai media estetika oleh Uecker menimbulkan kesan tersendiri. Bujono (Tempo, No. 25/XXXIV) menyebutkan: "Obyek-obyek murah tersebut membuat orang tertarik, terpaksa memperhatikan, dan tercekam. Karya tersebut seperti mengadukan sesuatu yang menyakitkan, menyiksa, sesuatu yang tidak manusiawi" Efek "menyakitkan" tersebut tampaknya muncul dari proses penancapan paku yang bisa dimana saja.

Pelukis Jerman lain yang juga memperoleh reputasi internasional dan salah satu pemuka utama seni kontemporer Jerman adalah Georg Baselitz. Ia pernah mendapatkan berbagai penghargaan dan karya-karyanya banyak dikoleksi oleh museummuseum terkemuka di dunia. Karyanya sempat dipamerkan di Indonesia pada tahun 2004 atas dukungan dari Goethe-Institut Jakarta dan IfA (Institut untuk hubungan luar negeri) di Stuttgart.

Ciri khas dari karya Baselitz adalah penampilan objek karyanya yang serba terbalik. Pembalikan ini bagi para pengunjung pamerannya menimbulkan sensasi tersendiri. Melalui karyanya, Baselitz seolah ingin menunjukan sebuah penggubahan yang cenderung menonjolkan aspek kerusakan bentuk atau proporsi, sehingga tidak menunjukan keterampilan seni gambar yang "indah". Ia ingin menampilkan daya ekspresi yang lebih murni dan tidak "dibuat (-buat)". Baselitz pernah mengatakan "Menggambar secara buruk jauh lebih sulit daripada menggambar (indah) yang tradisional"(Kompas, 2 Mei 2004) 
Diantara perupa Jerman yang mendapat tanggapan cukup baik, adalah Kathe Kölwitz yang hidup antara tahun 1867 hingga 1945. Ia merupakan salah satu perupa terkemuka Jerman di abad 20. Motiv utama yang ia geluti adalah sang maut atau kematian. Menurut Enin Supriyanto (Kompas, 9 Desember 2002), “dalam perkembangan seni rupa dunia, tampaknya kita memang harus menyebut nama Kathe Kölwitz pada urutan pertama perupa yang berhasil merekam, menafsirkan, dan menampilkan maut dan kematian di dalam karya seni rupa"

Dalam konteks kesenirupaan di Indonesia saat itu menjadi menarik, ketika karya Kathe Kölwitz tidak dipamerkan di Indonesia, namun motiv utama yang sering ia pakai dalam berkarya digunakan sebagai motiv yang dijadikan panduan untuk Trienal Grafis 2003 di Jakarta. Dipakainya motiv tersebut dalam kompetisi seni rupa di Indonesia menunjukan pula adanya pengaruh seni rupa Jerman terhadap seni rupa Indonesia, karena para perupa Indonesia seolah "dipaksa" untuk menggunakan motiv kematian dalam berkarya. Hal ini menunjukan bahwa kiprah Kathe Kölwitz diakui di Indonesia. Sebagai panduan dalam kompetisi tersebut, ditulislah esei khusus mengenai seniwati Jerman tersebut oleh kurator seni Bentara Budaya Jakarta, Enin Supriyanto.

Berdasarkan esei tersebut memang tampak jelas dan diakui bahwa Kolwitz merupakan seniwati Jerman yang sangat menonjol. Ia mampu memotret situasi zamannya yang kacau antara perang dunia I dan II. "Karya-karyanya mampu membawa gema pedih, kemiskinan, perlawanan, kerusuhan, perang, sekarat dan kematian (Supriyanto, Kompas, 09 Desember 2002). Pada saat itu Jerman memang sedang dilanda suasana yang chaos. Motiv kematian ataupun kemiskinan sepert ini dirasa penting untuk diangkat sebagai tema utama dalam Trienal Grafis 2003, karena tema tersebut saat ini terasa menghilang dari perenungan manusia modern di Indonesia yang tengah diserbu budaya kapitalistik dan hedonistik. 
Perupa Jerman dalam berkarya juga berusaha menyerap unsur budaya lain, khususnya budaya timur. Salah seorang diantaranya adalah Peter Dittmar, yang menyerap budaya timur khususnya Bali. Ia memperoleh tanggapan dari harian Kompas dan majalah Tempo.

Dittmar merupakan salah satu dari sekian banyak seniman atau perupa yang terpesona dengan kultur Bali. Namun, berbeda dengan kebanyakan perupa asing yang terpesona akan budaya Bali, ia tidak menonjolkan pada pesona alam yang eksotis. Dittmar lebih banyak mengambil inti (saripati) dari budaya timur khususnya Bali, sehingga karyanya banyak mereduksi pesona eksotis alam Bali menjadi bentuk yang sederhana. Eksplorasi yang dilakukan Dittmar, menurut Wiratha (Kompas, 09 Oktober 2005) menunjukan dua hal:

Pertama, sepanjang seabad ini, perupa mancanegara rupanya lebih banyak tertarik pada pesona visual kebudayaan Bali. Tapi, kedua, Dittmar menunjukkan, bahwa dibalik pesona visual itu, ada yang tak kalah menariknya, yakni pesona filosofis dari pancaran nilai di balik benda-benda tersebut.

Perupa Jerman lainnya yang juga banyak mengadopsi budaya timur adalah Markus Heinsdorf. Ia banyak menghasilkan karya berupa seni instalasi, terutama dengan menggunakan material bambu. Sebuah material yang banyak di temukan di Asia. Bahkan ia berkeinginan untuk membawa material bambu ke dalam pokok bahasan seni secara lebih luas. Bagi Heinsdorf, kebudayaan asia merupakan salah satu sumber pengetahuan yang memiliki kekuatan untuk menjadi inspirasi.

Dalam proyek instalasi berbahan bambu di Bali yang diberi judul The Skyplace, Heinsdorf mampu menunjukan sebuah karya rupa yang rumit (baik ditinjau dari segi perancangan hingga penyusunannya) dan sangat kaya. Karyanya ini dapat dikatakan merupakan hasil perpaduan budaya "timur" dan "barat" yang tidak saling beroposisi, tetapi malah saling mempengaruhi antar satu dengan yang lain. 
Diantara para perupa Jerman yang ada, terdapat beberapa kelompok perupa yang berpameran bersama di Indonesia, antara lain Monica Bonvicini, Albrecht Schafer dkk. Pameran mereka bertajuk "Seni Rupa d Berlin 1989 - 1999”. Dari judul pameran, tampak dengan jelas, bahwa pameran ini ingin menunjukan reaksi para seniman terhadap apa yang telah terjadi di Berlin selama 10 tahun terakhir setelah runtuhnya tembok Berlin yang menandai awal dari penyatuan Jerman. Pameran ini dirasa penting bagi upaya perbandingan dan perluasan pemahaman, terutama bagi proses kebudayaan.

Hampir sejalan dengan pameran yang dilakukan oleh Monica Bonvicini dkk, adalah pameran bersama yang dilakukan oleh Dieke Ambroster dan rekan-rekannya. Jika Bonvicini menampilkan karya mereka yang merupakan refleksi keadaan di Berlin setelah tembok Berlin runtuh melalui seni instalasi, maka Ambroster dan rekan menampilan poster-poster karya mereka yang juga menampilkan masa-masa saat Jerman sesudah bersatu. Pesan yang sangat kuat tertangkap adalah peringatan akan bahaya gerakan ultra-kanan dan pesan agar masyarakat Jerman tergerak memeranginya. Pesan tersebut terlihat sangat jelas baik dari juduljudul karya maupun dari tampilan secara visual.

Perupa Jerman lain yang memperoleh tanggapan positif adalah Wolf Vostell, Anna Anders dan rekan-rekannya yang memamerkan karya mereka dalam wujud seni video bertajuk The Scuplture. Pameran ini cukup penting, karena hingga tahun 2005 pameran ini merupakan pameran terbesar dan terpenting seni berteknologi video yang pernah diselenggarakan di Indonesia, dan dalam pameran ini ditampilkan karya para pelopor seni video Jerman di tahun 60-an hingga generasi keempat. Karya mereka ini telah dibawa ke berbagai negara sejak tahun 1994 dengan disponsori oleh Goethe-Institut dan IfA.

Dengan menyaksikan pameran ini, dapat diketahui perkembangan seni berteknologi video di Jerman dan relevansinya dengan perkembangan seni video di dunia. Dalam konteks seni 
rupa (khususnya seni video) di Indonesia, pameran ini menjadi tantangan tersendiri. Murti (Kompas, 12 Juni 2005) mengatakan:

Dari pameran ini seolah membuka cakrawala yang lebih luas, tidak saja kemampuan teknologi mampu merambah wilayahwilayah baru, namun melalui kemungkinan teknologi itulah manusia menyiasati diri untuk melihat realitas dan dirinya lebih baik Bagi para pekerja video Indonesia yang umumnya masih cenderung berkutat dalam video single channel yang mengasosiasikan film seni yang lain, tentu proyek ini menjadi tantangan.

Adanya sejumlah pameran perupa Jerman di Indonesia, terlihat dari pihak Jerman muncul usaha yang cukup intensif untuk memperkenalkan seniman Jerman dan karyanya kepada masyarakat Indonesia, karena sebagian besar pameran-pameran para perupa Jerman di Indonesia ini didukung oleh Goethe-Institut dan IfA, dua lembaga yang membidangi kerjasama kebudayaan di luar negeri. Para perupa Jerman tersebut kemudian memperoleh tanggapan dari seniman, kritikus seni atau kurator yang menuliskan "pembacaannya" di harian Kompas dan majalah Tempo.

Para penulis tersebut merupakan pembaca aktif atau kreatif yang menuliskan artikelnya di media massa. Berdasarkan pemikiran Fish (Allen, 2004: 8-9) yang menyatakan bahwa pembaca tidak "sekedar" membaca dalam suatu cara yang sematamata, asal membaca, fenomena tersebut memiliki makna tersendiri. Pembaca tidak mendekati sebuah teks dengan kepala kosong; mereka juga membawa harapan, asumsi, dan pengalaman, baik yang dilakukan secara ideologis (strategi interpretif yang sengaja diambil) atau melalui bawah sadarnya yang berupa "kopor pembaca". Dengan demikian para penulis tersebut -yang sebagian besar berkecimpung di dunia seni rupa - memiliki suatu horizon harapan dalam bersingungan dengan karya perupa Jerman sebagai suatu wawasan baru di Indonesia.

Para perupa Jerman tersebut dianggap cukup penting untuk diletakan dalam konteks kesenirupaan di Indonesia, bahkan beberapa dapat ditempatkan sebagai "trendsetter" dalam seni rupa 
Indonesia. Hal ini tampak pada perupa Jerman yang terkenal seperti Kathe Kölwitz, Max Ernst, Wolf Vostell, Sigmar Polke, Georg Baselitz dan Guenther Uecker. Pengaruh mereka mungkin belumlah sebesar pengaruh para pemikir Jerman yang pemikiran mereka sangat banyak mempengaruhi peta pemikiran kalangan menengah atas di Indonesia (Santoso dan Swandayani, 2009). Meskipun demikian, munculnya tanggapan terhadap perupa Jerman tetap dapat dianggap sebagai awal penetrasi budaya Jerman ke dalam budaya Indonesia, terutama dalam bidang seni rupa. Dan dari sinilah proses akulturasi akan terus berlanjut.

Jika ditelusuri lebih jauh, para penulis dan redaktur sebenarnya telah memiliki implied reader (Pembaca yang dibayangkan) terhadap pemuatan artikel-artikel tersebut. Pembaca yang dibayangkan inilah yang menjadi "komunitas interpretasi" atas karya perupa Jerman tersebut. Komunitas interpretasi tersebut adalah para seniman, penikmat seni, pengamat seni dan kalangan menengah atas pada umumnya. Hal ini sesuai dengan para pembaca harian Kompas dan majalah Tempo yang sebagian besar adalah kalangan menengah atas. Media massa ini setidaknya menjembatani perupa Jerman dalam rangka memperkenalkan pandangan dan proses kreatif mereka ketika berkarya guna membantu pembacanya di Indonesia untuk memperluas wawasan. Kalangan menengah atas ini merupakan satu unsur penting dalam menentukan perkembangan sejarah di Indonesia, termasuk perkembangan seni budaya.

Williams (1988: 88 - 93) mengemukakan bahwa karya sastra, Film, teater, musik, seni rupa dan unsur budaya lainnya merupakan situs hegemoni, yakni tempat pertarungan ideologi berlangsung. Berdasarkan teori hegemoni Gramscian, produk seni budaya merupakan tempat refleksi pandangan dunia masyarakat pendukungnya, tetapi sekaligus juga sebagai medium untuk mengkonstruksi masyarakat. Mengacu pada pandangan tersebut. Bisa diduga bahwa pandangan kalangan menengah atas juga bisa dipengaruhi oleh perkembangan arus pemikiran para perupa 
Jerman. Mereka setidaknya bisa menjadi contoh ataupun sumber inspirasi bagi seniman Indonesia. Inilah salah satu bentuk konstruksi sosial di Indonesia.

\section{SIMPULAN}

Tulisan singkat ini ingin mengungkapkan fenomena mutakhir dalam bidang kebudayaan, terutama seni rupa, dengan mengkaji tanggapan para penulis Indonesia terhadap para perupa Jerman dan karya-karya mereka.

Berdasarkan apa yang telah disampaikan sebelumnya, maka dapat disimpulkan beberapa hal sebagai berikut. Pertama, terdapat 50 perupa yang memperoleh tanggapan dari pembaca kreatif di Indonesia yang dituangkan dalam 17 artikel di harian Kompas dan majalah Tempo yang terbit antara tahun 2000 hingga 2007. Para perupa yang ditampilkan kesemuanya adalah para perupa modern Jerman abad 20 dan 21, dan sebagian besar mewakili seni kontemporer. Para perupa tersebut secara garis besar dapat digolongkan dalam tiga kategori. Golongan pertama adalah para perupa yang telah memiliki reputasi internasional sehingga karya mereka banyak di koleksi oleh berbagai museum di dunia dan telah memperoleh berbagai penghargaan. Kelompok ini merupakan pioneer di dunia kesenirupaan Jerman modern. Diantara mereka yaitu Kathe Kölwitz, Max Ernst, Wolf Vostell, Sigmar Polke, Georg Baselitz dan Günther Uecker. Kelompok kedua adalah perupa yang menyerap unsur budaya timur dan Bali. Dari sini terlihat bahwa proses akulturasi dua budaya yaitu barat dan timur memperoleh tempatnya. Dengan demikian dalam diri mereka terjadi proses akulturasi yang bersifat timbal balik. Perupa tersebut adalah Markus Heinsdorf, Peter Dittmar dan Wolfgang Thesen. Sedang kelompok terakhir adalah para perupa yang secara khusus berpameran di Indonesia dengan mengusung karya-karya mereka yang berusaha menyampakan pesan mengenai situasi di Jerman 
pasca runtuhnya tembok Berlin. Mereka adalah Monica Bonvicini, Dieke Ambroster beserta rekan-rekannya.

Kedua, para perupa dari Jerman tersebut diresepsi sebagai tokoh-tokoh yang mempelopori berbagai aliran dalam seni rupa. Secara umum, para perupa Jerman tersebut ditanggapi secara positif oleh para penulis di harian Kompas dan majalah Tempo. Para penulis tersebut kebanyakan dating dari kalangan seniman, kritikus seni, dosen dan kurator seni.

Ketiga, media massa Indonesia dalam hal ini harian Kompas dan majalah Tempo secara tidak langsung telah membentuk semacam komunitas interpretasi, yaitu sebagai "trendsetter" di bidang seni rupa. Hal itu sekaligus merupakan salah satu bentuk formasi sosial pembentuk kelas menengah di Indonesia.

Berdasarkan kesimpulan tersebut, tulisan ini diharapkan dapat memberikan wawasan yang lebih luas pada pembaca di Indonesia dalam mengkritisi bentuk-bentuk akulturasi budaya yang diwakili bidang senirupa. Masyarakat diharapkan akan menjadi "pembaca" yang kritis dalam menyikapi serbuan budaya asing terkait dengan proses pembentukan budaya nasional. Sikap kritis sangat diperlukan karena karya-karya seni rupa dalam bentuk apapun selalu membawa pesan ideologi yang diusung oleh penciptanya.

\section{DAFTAR PUSTAKA}

Allen, Pamela. 2004. Membaca dan Membaca Lagi; (Re)Interpretasi Fiksi Indonesia 1980 - 1995.(Terj. Bakdi Soemanto). Magelang: Indonesiatera.

Bujono, Bambang. "Kekejaman Manusia atas Manusia" dalam Tempo, No. 25/XXXIV/15 - 21 Agustus 2005

Derenthal. Ludger. "Jejak Seni Primitif pada Max Ernst" dalam Kompas, 07 Januari 2007. 
Efix, "Dunia Terbalik Georg Baselitz" dalam Kompas, 2 Mei 2004

Hujatnikajennong, Agung. "Sigmar Polke: Subversi FragmenFragmen Tak Dikenal" dalam Kompas, 06 Agustus 2006

Jausz, Hans Robert, 1974. "Literay History as a Challenge to Literary Theory, " dalam New Directions in Literary History (Ralph Cohen, ed). London: Logman.

Kubitschek, Hans Dieter., Wessel, Inggrid. 1981 Geschichte Indonesiens. Berlin: Akademie Verlag.

Lombard, Denys. 2000. Nusa Jawa: Silang Budaya, Kajian Sejarah Terpadu Bagian I Batas-Batas Pembaratan. Jakarta: Gramedia Pustaka Utama.

Murti, Krisna. "Proyek Pemetaan Seni (Rupa) Video? *Dari Pameran Video "Sculpture" di Jerman sejak 1963 - Seni" dalam Kompas, 12 Juni 2005

Santoso, Iman dan Swandayani, Dian. 2009 "Resepsi Atas Pemikirpemikir Jerman dalam Media Cetak Indonesai Pada Awal Abad XXI" dalam Jurnal Penelitian Humaniora. Vol 14, No. 1, April 2009. Yogyakarta: Lembaga Penelitian, Universitas Negeri Yogyakarta

Siebert, Rüdiger. 2002. Berjejak di Indonesia: Kisah Hidup Sepuluh Tokoh Jerman. Jakarta: Penerbit Katalis.

Supriyanto, Enin. "Kölwitz, Kematian dan Kita" dalam Kompas, 9 Desember 2002

Toffler, Alvin. 1991. Pergeseran Kekuasaan. Jakarta: Pantja Simpati.

Wiratha, Putu Dwikora. "Eksplorasi Trans-Kultur Peter Dittmar" dalam Kompas, 9 Oktober 2005. 
Resepsi Atas Perupa Jerman pada Harian Kompas dan Majalah Tempo Edisi 2000 - 2007 (Dian Swandayani, Nurhadi, Iman Santoso)

Williams, Raymond. 1988. "Dominant, Residual, and Emergent," dalam K.M Newton, Twentieth Century Literary Theory. London: MacMillan Education Ltd. 